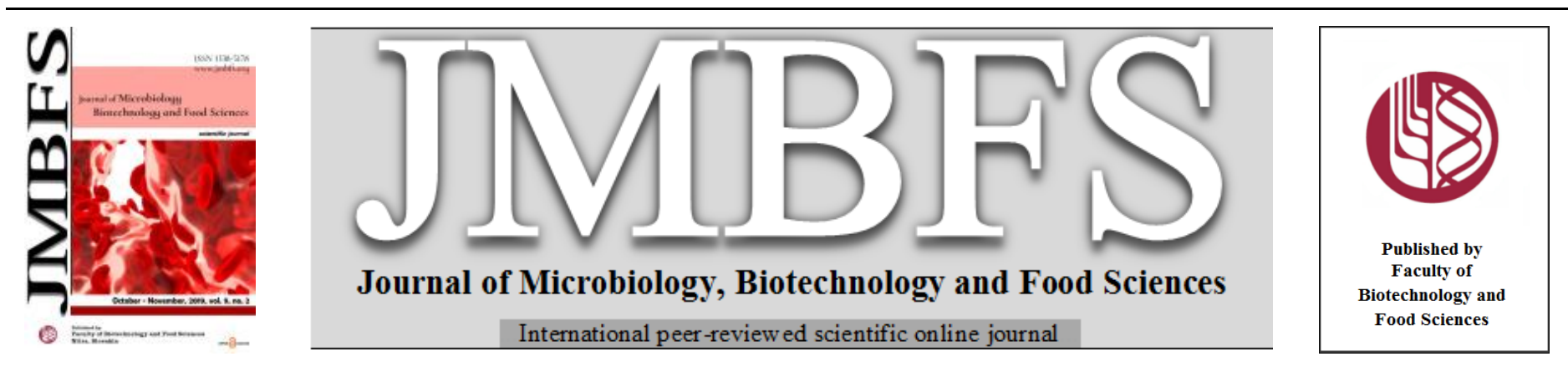

\title{
DETERMINATION OF MYCOBIOTA AND MICROBIAL LOADS OF GRAPES GROWN IN BOZCAADA, TURKEY
}

\section{Gülçin ÖZCAN ATEŞ ${ }^{l}$, Nükhet Nilüfer DEMİREL ZORBA ${ }^{2 *}$}

\author{
Address(es): \\ ${ }^{1}$ Çanakkale Onsekiz Mart University, Health Services Vocational School, Çanakkale, Turkey. \\ ${ }^{2}$ Çanakkale Onsekiz Mart University, Faculty of Engineering, Food Engineering Department, Çanakkale, Turkey.
}

*Corresponding author: dnukhet@ comu.edu.tr/dnukhet@hotmail.com

doi: $10.15414 / j m b f s .2020 .9 .5 .899-906$

\section{ARTICLE INFO}

Received 22. 4. 2019

Revised 20. 10. 2019

Accepted 22. 10. 2019

Published 1. 4. 2020

Regular article OPEN $\partial_{\text {ACCESS }}$

\begin{abstract}
Bozcaada which is a province of Çanakkale, Turkey, is located between the $39^{0} 48$ north parallel and $26^{0}$ east meridians. The largest livelihood of Bozcaada is viticulture. Therefore, in our study, microbial load, and mould diversity of the Cavus (table) and Karalahna (wine) grapes which are endemic to the island were evaluated, and ochratoxin production potentials of Aspergillus isolates were investigated by HPLC. A total of 6 vineyards with Çavuş and Karalahna grapes were sampled in 2015 and 2016. Total aerobic mesophilic bacteria count of grapes ranged between 0.00 and $4.21 \mathrm{log}$ CFU/g, yeast load between 0.00 and $2.66 \log \mathrm{CFU} / \mathrm{g}$ and mould load between 1.67 and $3.20 \mathrm{log}$ CFU/g. A total of 2264 mould isolates were taken from samples. All isolates were identified at the genus level. Aspergillus spp. and Penicillium spp. were the most isolated species in 2015, while Alternaria spp. and Cladosporium spp. were the most isolated species in 2016. It was determined that 13.78\% (312) of the isolates were Aspergillus spp., 54 of these isolates, have been selected and identified at the species level. Twenty-one of the black Aspergillus isolates were identified as A. niger / A. acidus, twenty-four of them were A. carbonarius and one of them is A. ibericus. The two white isolates were found to be A. candidus, the creamy brownish-spore forming isolate was A. terreus, and three green isolates were identified as A. flavus, A. calidoustus and A. sydowii. Six isolates $(4$ A. niger, 1 A. calidoustus, and 1 A. sydowii) were producing OTA. The amounts of ochratoxins varied from 0.80 to $74.01 \mathrm{ng} / \mathrm{g}$.
\end{abstract}

Keywords: Çavuş grape; Karalahna grape; mould; Aspergillus spp.; OTA

\section{INTRODUCTION}

The low $\mathrm{pH}$ and high water activity of fruits together with the carbon and nitrogen contents allow for the growth of moulds (Beuchat, 1987; Pitt and Hocking, 2009). The presence of microorganisms in different groups and species depends on the maturity and the nutrients contents of the grape (Barata $\boldsymbol{e t}$ al., 2012; Martins et al., 2012; Wang et al., 2015).

There are many internal and external factors affecting microorganism reproduction on the surface of grapes, such as temperature, rains, grape variety, maturity, physical damage caused by birds or insects, location of the vineyard, whether or not pesticides are used. In addition to these, the presence of the cuticle layer, which affects the microbial cell adhesion and the colonisation of the microbial cells on the outer surface of the grape berry, is also an important factor Despite all these facts, there is no precise information about how the microorganisms contaminate the surface of grapes and colonise them (Fleet, 1999)

Presence of Alternaria spp., Aspergillus spp., Botrytis cinerea, Cladosporium spp., Penicillium spp., and Rhizopus spp. are reported in grapes, and these moulds cause spoilage in grapes. Besides, Botrytis cinerea and Rhizopus spp. are postharvest primary pathogens for grapes in many countries. In addition to these species, some other mould species have also been reported in studies on grapes. (Sage et al., 2004; Tournas and Katsoudas, 2005; Battilani et al., 2006; Bejaoui et al., 2006; Lasram et al., 2012; Tian et al., 2015). Moulds in grapes do cause not only economic losses but also mycotoxigenic moulds are importan for human health (Battilani et al., 2006).

Grape as a perishable fruit is highly susceptible to infections known as black mould caused by Aspergillus niger during harvest and storage. Some strains of Aspergillus niger are capable of producing ochratoxin $\mathrm{A}$, and this toxin is a highly dangerous secondary metabolite. Ochratoxin A is classified as possibly carcinogenic (group 2B) by the International Agency for Research on Cancer (IARC). Therefore, it is very important to use safe and effective methods to control this disease in stored grapes (Wang et al., 2015; Tian et al., 2015).

In this study; it was aimed to determine the microbial loads and mould species in the ripening period of Bozcaada's Çavuş and Karalahna grapes. No literature has been found on the determination of the mould microbiota of Bozcaada grapes. The island also consists of fungus-borne diseases from time to time in the vineyards and affects grape quality. Therefore, in this study, it was tried to determine the moulds on the surface of the grapes during the ripening process in Bozcaada.

\section{MATERIALS AND METHODS}

Study area and sampling

In this study, six vineyards were chosen for grape sampling during 2015 and 2016 harvest season in Bozcaada. Cavus (table ) and Karalahna (wine) grapes were used as the material. These grapes are unique to Bozcaada. Bozcaada (Tenedos) is located between $39^{\circ} 48^{\prime}$ north parallel and $26^{\circ} 02^{\prime}$ east meridians in the north-east Aegean Sea. It is a district of Çanakkale province, Turkey. Bozcaada has the characteristics of the Mediterranean climate due to the geographical position, and it takes both northern and southern winds. Since it is located at the exact exit of the Bosphorus, and the northern winds are dominant in the island, viticulture is high on the island. Table grapes grow on the island as well as wine grapes. Bozcaada grapes are processed in six wine factories located on the island and some of them marketed to abroad (Dardeniz et al., 2007; Anonymous, 2015)

Firstly, two different regions were chosen in Bozcaada where more common vineyards are found. Vineyards are located in the Cayır (north of the island) and Sulubahçe (south of the island) district. Then, considering the altitude differences in these regions, the vineyards were determined. For Çavuş Grape, four vineyards were selected. However, Karalahna vineyards are limited on the island. Thus one vineyard was chosen from each district. The sample area information was given in Table 1. As a result, a total of 6 samples were collected in each sampling day. Sampling day and codes were given in Table 2 . 
Table 1 Altitude, locations and vineyards of grape samples

\begin{tabular}{ccccc}
\hline Code & $\begin{array}{c}\text { Grape } \\
\text { variety }\end{array}$ & $\begin{array}{c}\text { Distinct of } \\
\text { island }\end{array}$ & Location & Altitude \\
\hline ÇÇ1 & Çavuş & Çayır & $\begin{array}{c}39^{\circ} 50^{\prime} 12^{\prime \prime} \mathrm{K}- \\
26^{\circ} 2^{\prime} 19^{\prime \prime} \mathrm{D}\end{array}$ & $0 \mathrm{~m}$ \\
ÇÇ2 & Çavuş & Çayır & $\begin{array}{c}39^{\circ} 50^{\prime} 15^{\prime \prime} \mathrm{K}- \\
26^{\circ} 2^{\prime} 38^{\prime \prime} \mathrm{D}\end{array}$ & $20 \mathrm{~m}$ \\
ÇK & Karalahna & Çayır & $\begin{array}{c}39^{\circ} 50^{\prime} 14^{\prime \prime} \mathrm{K}- \\
26^{\circ} 2^{\prime} 39^{\prime \prime} \mathrm{D}\end{array}$ & $30 \mathrm{~m}$ \\
SÇ1 & Çavuş & Sulubahçe & $\begin{array}{c}39^{\circ} 49^{\prime} 8^{\prime \prime} \mathrm{K}-26^{\circ} \\
0^{\prime} 38^{\prime \prime} \mathrm{D}\end{array}$ & $30 \mathrm{~m}$ \\
SÇ2 & Çavuş & Sulubahçe & $\begin{array}{c}39^{\circ} 49^{\prime} 7^{\prime \prime} \mathrm{K}-26^{\circ} \\
1^{\prime} 0^{\prime \prime} \mathrm{D}\end{array}$ & $40 \mathrm{~m}$ \\
SK & Karalahna & Sulubahçe & $\begin{array}{c}39^{\circ} 49^{\prime} 13^{\prime \prime} \mathrm{K}- \\
26^{\circ} 0^{\prime} 44^{\prime \prime} \mathrm{D}\end{array}$ & $20 \mathrm{~m}$ \\
\hline & & & &
\end{tabular}

Table 3 Meteorological data of vineyards

\begin{tabular}{|c|c|c|c|c|c|c|}
\hline \multirow[b]{2}{*}{ Vineyard } & \multicolumn{3}{|c|}{2015} & \multicolumn{3}{|c|}{2016} \\
\hline & $\begin{array}{c}\text { Tmin-Tmax } \\
\left({ }^{\circ} \mathrm{C}\right)\end{array}$ & $\begin{array}{c}\text { Humidity (\%) } \\
\text { min-max }\end{array}$ & $\begin{array}{l}\text { Wind speed } \\
\min -\max \end{array}$ & $\begin{array}{c}\text { Tmin-Tmax } \\
\left({ }^{\circ} \mathrm{C}\right)\end{array}$ & $\begin{array}{c}\text { Humidity (\%) } \\
\text { min-max }\end{array}$ & $\begin{array}{c}\text { Wind speed } \\
\text { min-max }\end{array}$ \\
\hline ÇÇ2 & $24-26$ & $56-74$ & $2-37$ & $23-31$ & $35-74$ & $16-32$ \\
\hline ÇK & $22-26$ & $56-77$ & $2-37$ & $23-31$ & $35-75$ & $16-32$ \\
\hline SÇ1 & $23-27$ & $66-74$ & $10-37$ & $23-32$ & $38-83$ & $18-35$ \\
\hline SK & $23-29$ & $66-75$ & $10-37$ & $23-31$ & $36-83$ & $13-35$ \\
\hline
\end{tabular}

A total of 11 samplings were carried out during the two years. 500-750 g (2 clusters of, firm berries) samples were taken separately for microbiological and other analysis from each vineyard at sampling date (Medina et al., 2005; Renouf et al., 2005).

\section{Determination of physical and chemical properties of grapes}

Grape samples were first placed in stomacher bags and were crushed in Bag Mixer (Interscience, Italy) for $1 \mathrm{~min}$. The crushed grapes were then filtered with the help of cheesecloths to obtain grape juice. The $100 \mathrm{~mL}$ of filtered liquid was collected in glass jars and stored at $-20^{\circ} \mathrm{C}$ until analysis. The $\mathrm{pH}$ of the grape juice was determined using a pH meter (IQ Scientific Instruments Model IQ150, USA) at $20^{\circ} \mathrm{C}$ (Güven, 2008). - The acidity of grape juice is determined by the potentiometric method (Güven, 2008). The amount of water-soluble dry matter (WSDM) (\%) of grape juice was determined by measuring with Atago Pocket Pal-1 (Japan) hand refractometer (Güven, 2008). All analyses were performed in triplicate.

\section{Determination of air yeast and mould loads}

The passive method was used to determine the microbiological load of the air Dichloran Rose Bengal Chloramphenicol Agar (DRBC) (Merck 1.00466) medium containing plates were open for 10 minutes at an altitude of about $25 \mathrm{~cm}$, while the samples were collected (Meyvacı et al., 2012).

\section{Determination of grape microbiota}

The grape samples were collected on the morning of the sampling day. Grape clusters were placed in clean fridge pouches and delivered to the laboratory in the cold chain. The samples brought to the laboratory were stored at $+4^{\circ} \mathrm{C}$ until the analysis, and they were analysed on the same day.

$25 \mathrm{~g}$ of the collected samples were taken into stomacher bag containing $225 \mathrm{~mL}$ of $0.1 \%$ peptone water (Oxoid, CM0009) and the bag was shaken at $150 \mathrm{rpm}$ for 10 min (Heidolph Unimax 2010, Germany). Serial dilutions were then prepared with $0.1 \%$ peptone water (Oxoid, CM0009). From prepared dilutions, Total aerobic mesophilic bacteria (TAMB) count was performed according to the pour plate method. Mould and yeast count were made according to the spread plate method. Plate Count Agar (PCA) (Merck 1.05463) was used for TAMB, and both Dichloran 18\% Glycerol Agar (DG18) (Merck 1.00465) and Dichloran Rose Bengal Chloramphenicol Agar (DRBC) (Merck 1.00466) were used for mould and yeast counting. PCA plates were incubated for $48 \pm 2$ hours at $37^{\circ} \mathrm{C}$, DG18 plates for $72 \pm 2$ hours at $25^{\circ} \mathrm{C}$ and DRBC plates at $25^{\circ} \mathrm{C}$ for five days. After the incubation, the total aerobic mesophilic bacteria, yeast and mould loads in the grapes were determined (Battilani et al., 2006, Melki Ben Fredj et al., 2007, Samson et al., 2010, Meyvaci et al., 2012, Chunmei et al., 2013).
Table 2 Sampling dates and codes

\begin{tabular}{cc}
\hline Code & Sampling Date \\
\hline S1 & 04 August 2015 \\
S2 & 14 August 2015 \\
S3 & 24 August 2015 \\
S4 & 04 September 2015 \\
S5 & 20 June 2016 \\
S6 & 30 June 2016 \\
S7 & 10 July 2016 \\
S8 & 20 July 2016 \\
S9 & 01 August 2016 \\
S10 & 11 August 2016 \\
S11 & 22 August 2016 \\
\hline
\end{tabular}

The locations of the vineyard grapes were determined GPS. Meteorological data such as mean temperature, mean humidity and mean wind speed was recorded while grape samples were taken (Melki Ben Fredj et al., 2007; Meyvacı et al., 2012). Meteorological data were given in Table 3.

\section{Isolation of moulds}

Moulds with different colony morphology were selected from Petri dishes. While taking mould isolates, the counting result was taken into consideration and isolates were taken according to their amount in the sample. The isolates were plated according to three-point inoculation method into PDA medium and incubated at $25^{\circ} \mathrm{C}$ for 3-5 days. At the end of the incubation, the pure cultures were harvested and inoculated to PDA slants and incubated at $25^{\circ} \mathrm{C}$ for $7-14$ days. Then, spore solutions of the isolates were prepared by adding $0.2 \%$ agar + $0.05 \%$ Tween 80 into the tubes. Prepared spore solutions were stored at $+4^{\circ} \mathrm{C}$ and morphological and cultural identification of moulds were made from these spore solutions (Samson et al., 2010; Özcan, 2017).

Identification of fungal isolates according to morphological and cultural characteristics

Preliminary identification of mould genus was determined by microscopically by using lactophenol blue (Merck 113741) preparations. The preparations were examined on a light microscope (Olympus CX31, Japan). Isolates were identified as a genus according to conidiophore, sporangiophore, spore heads, spores, exudates etc. and colony morphology (Pitt and Hocking, 2009; Samson et al., 2010).

When isolate did not produce spore for seven days at $25^{\circ} \mathrm{C}$ on PDA medium, isolates were incubated up to 14 days. At the end of the incubation, isolates which did not contain spores were cultured on Malt Extract Agar (MEA) medium and incubated for 14 days at $25^{\circ} \mathrm{C}$. The isolates that did not contain spores also in the MEA medium were defined as sterile hyphae.

\section{Identification of Aspergillus spp.}

Isolates of Aspergillus spp. were identified using the keys given according to Samson et al., (2007); Samson et al., (2010) and Samson et al., (2014). Firstly, these isolates were plated in Czapek Yeast Extract Agar (CYA), MEA and Creatine Sucrose Agar (CREA) media as three-point inoculation and incubated at $25^{\circ} \mathrm{C}$ for seven days in the dark. Colony diameters and colony appearance and morphological features of fruiting bodies and spores were determined after seven days of the incubation period. Diameters of conidial heads and, conidia were measured by using an ocular micrometre. Also, the MEA medium was incubated at $15^{\circ} \mathrm{C}, 36^{\circ} \mathrm{C}$, and $40^{\circ} \mathrm{C}$ for ten days and CYA medium was incubated at $30^{\circ} \mathrm{C}$ and $37^{\circ} \mathrm{C}$ for seven days. At the end of the incubation period, Colony diameters and colony appearance and morphological features of fruiting bodies and spores were also determined.

\section{Determination of OTA production by HPLC-FLD}

The extraction of OTA was performed as described by Samson et al. (2010) with small modifications We used $500 \mu \mathrm{L}$ methanol:dichloromethane: ethyl acetate (1:2:3 in $1 \%$ formic acid) solution and applied 30 minutes ultrasound for 
mycotoxin extraction. In the OTA analysis, AOAC Official 2000.03 (AOAC, 2002) method with some modifications was used. It was performed in Canakkale Food Control Laboratory which is accredited (AB-0283-T) in mycotoxin analysis. Ochraprep immunoaffinity columns (R-biopharm, Darmstadt, Germany) were used and the extract obtained from grown mould species were was passed through the column at a constant speed of 1-2 drops per second, and the OTA was retained by the antibody. After that, the column was washed with ten $\mathrm{mL}$ of $0.01 \%$ Tween 20 phosphate buffer solution and ten $\mathrm{mL}$ of ultra-pure water at the same rate. OTA separated from the column by passing one $\mathrm{mL}$ methanol-acetic acid (98:2, v/v) (Merck, Germany) at a constant rate of about one drop per second and the eluate is collected in a clean vial. Then, $1.5 \mathrm{~mL}$ of ultrapure water (Elga, UK) was added to the eluate and vortexed. The eluate obtained was stored at $4^{\circ} \mathrm{C}$ until analysis on HPLC. UPLC Shimadzu DGU 20A5R (South America) device and fluorescent detector (FLD) were used for the analysis of ochratoxin. Column C18 (Spherisorb ODS2 Column $80 \AA, 5 \mu \mathrm{m}, 4,6 \mathrm{~mm} \mathrm{X} 250 \mathrm{~mm}$, Serial No 25161005, Waters Corporation, USA) was used as the column. The mobile phase was acetonitrile (Merck, Germany): acetic acid $(0.004 \%)$ containing pure water $(48: 52 ; \mathrm{v} / \mathrm{v})$. The flow rate is one $\mathrm{mL} / \mathrm{min}$, and the column temperature is $40^{\circ} \mathrm{C}$, the injection volume is $100 \mu \mathrm{L}$. The fluorescence detector used in the wavelength excitation is $333 \mathrm{~nm}$, the emission is $443 \mathrm{~nm}$.
All isolates that were grown on both CYA and Yeast Extract Sucrose Agar (YES) medium were used. In the study, HPLC performance parameters such as linearity, determination limit (LOD), measurement limit (LOQ), repeatability and reproducibility were also determined.

\section{Statistical analysis}

Non-parametric Kruskal-Wallis test was applied in the Minitab 17.0 program to determine whether there is a statistical difference between the sampling date, the grape variety, and vineyard location and the year, on the microbial load of the grapes, Non-parametric tests are used for variables with no normal distribution. Since the $\mathrm{pH}$, WSDM and titration acidity values of the grapes were normally distributed; One-Way ANOVA Tukey test was performed to evaluate the difference of these values.

\section{RESULTS AND DISCUSSION}

Physical and chemical properties of grapes

The data of $\mathrm{pH}$, water-soluble dry matter (WSDM), and titration acidity (TA) values were given in Table 4.

Table 4 Grape samples pH, WSDM, and TA values.

ÇÇ1 ÇÇ2

$\begin{array}{llllllllllllllllllllllllll}\text { PH } & \text { WSDM } & \text { TA } & \text { PH } & \text { WSDM } & \text { TA } & \text { PH } & \text { WSDM } & \text { TA } & \text { PH } & \text { WSDM } & \text { TA } & \text { PH } & \text { WSDM } & \text { TA } & \text { PH } & \text { WSDM } & \text { TA }\end{array}$

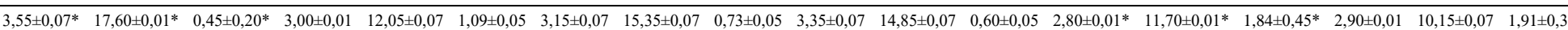

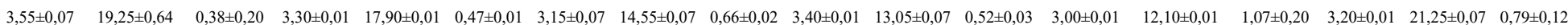

$3,45 \pm 0,07 \quad 15,60 \pm 0,01 \quad 0,46 \pm 0,02$

$3,65 \pm 0,01 \quad 17,65 \pm 0,07 \quad 0,37 \pm 0,02$

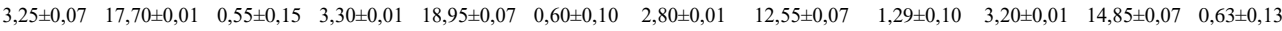

$\begin{array}{lllllllllllll}3,47 \pm 0,01 & 21,60 \pm 0,01 & 0,37 \pm 0,05 & 3,41 \pm 0,01 & 20,70 \pm 0,01 & 0,42 \pm 0,05 & 3,09 \pm 0,01 & 16,35 \pm 0,07 & 0,69 \pm 0,10 & 3,45 \pm 0,01 & 21,90 \pm 0,01 & 0,47 \pm 0,03\end{array}$

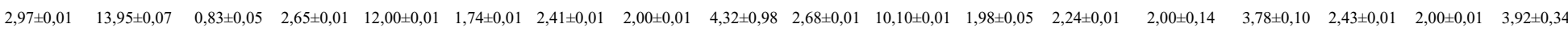

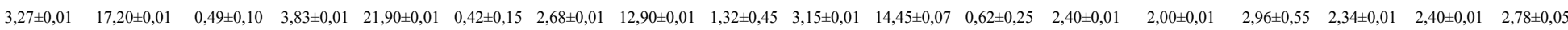

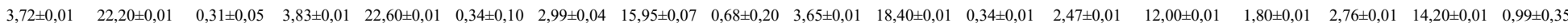

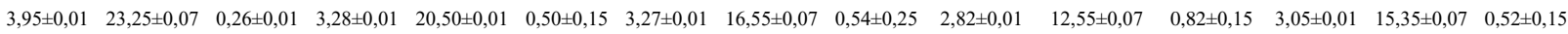

*: Results are given as mean \pm standard deviation.

-: No analysis was performed because grape samples were cut.

Studies on the physical and chemical properties of different varieties of grapes were available in the literature. In our study, $\mathrm{pH}$, WSDM and TA of Çavuş and Karalahna grapes were determined in two years. The $\mathrm{pH}$, WSDM and TA values were different from the studies in the literature (Li et al., 2010; Chunmei et al., 2013). It was thought that the reasons for the differences in physical and chemical properties were caused by factors such as grape variety, location and sampling time. Two years data were evaluated together and it was seen that the effect of the vineyard location $(P=0.000)$, year $(P=0.000)$, sampling day $(P=0.000)$, and grape varieties $(P=0.000)$ on $\mathrm{pH}$ values of samples were statistically significant.
In WSDM and TA data, it was seen that the effect of year $(P=0.000)$, sampling day $(P=0.000)$, and grape varieties $(P=0.012$ and $P=0.043$ respectively $)$ were statistically significant while vineyard location was not statistically significant ( $P=0.127$ and $P=0.162$ respectively)

\section{Yeast and mould loads of vineyards air in during sampling}

The mould-yeast loads of air during sampling were given in Figure 1.

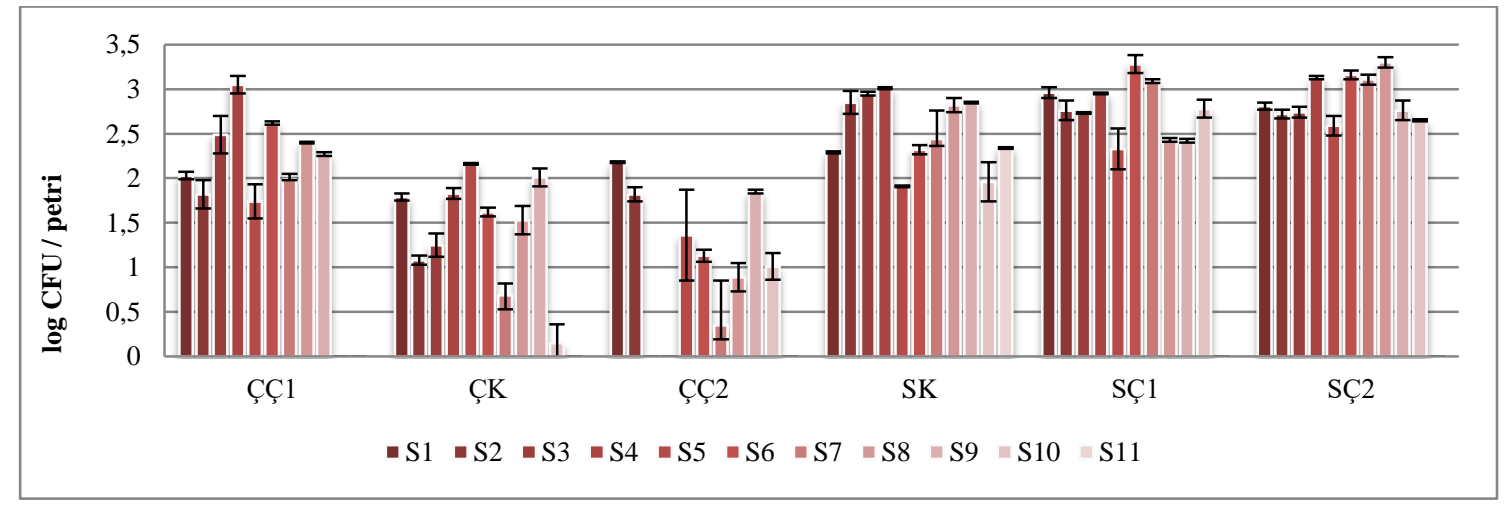

Figure 1 The yeast-mould loads of vineyards air. (Results are given as mean \pm standard deviation.)

- No analysis was performed because grape samples were harvested

As it was shown in Figure 1, the mould-yeast load of the air in Çayır district ranged from $1.08 \pm 0.05$ to $3.05 \pm 0.01 \log$ CFU/Petri, whereas in Sulubahçe district, it was between $2.29 \pm 0.01$ and 3.13 $\pm 0.02 \log$ CFU/Petri in 2015. In 2016, in Çayır and Sulubahçe areas, it was found to be between $0.15 \pm 0.21$ and $2.62 \pm 0.02 \log \mathrm{CFU} /$ Petri and $1.91 \pm 0.01$ to $3.30 \pm 0.06 \log \mathrm{CFU} /$ petri respectively. In Çavuş variety, It was determined that the mould load of air in Çayır district is variable and there is less difference in the air loads of vineyards in Sulubahçe district. It was observed that the mould-yeast load of the air in the Çavus vineyards in Sulubahçe is higher than the vineyards found in Çayır district. However, considering the whole vineyards, the air mould-yeast load air in 2016 is lower than in 2015. In the Karalahna variety, It was determined that the air mould-yeast load was higher in Sulubahçe region in both years. In 2015, the mould-yeast load of all Karalahna vineyards was higher than in 2016.

The air mould load of the vineyards in the Sulubahce was higher than Cayir district. As a result of the non-parametric Kruskal Wallis statistical analysis, it was determined that the effect of vineyard location $(P=0.000)$ and sampling day $(P=0.014)$ on the mould-yeast load of air was significant in 2015 . In 2016, it was determined that only the vineyard location $(P=0.000)$ have a significant effect on the mould-yeast load of air. When the data collected in two years were evaluated together, it was determined that the effect of the vineyard location $(P=0.000)$ on the mould-yeast load of the air was statistically significant. However, it was 
found that there was no statistically significant difference between the year $(P=0.051)$ and sampling day $(\mathrm{P}=0.126)$ on-air mould-yeast load in the vineyards. The most important reason for these differences was the wind speed and direction. The wind direction, in particular, changes the mould types and the load of the air and the speed, in particular, affects the load being transported.

Chunmei et al. (2013) reported that the air load varied between $31.3 \pm 1.3$ and $246.7 \pm 13.2 \mathrm{CFU} /$ petri depending on the vineyards in China. In our study, It was determined that the air load was between 0.00 and $3.00 \log$ CFU/Petri and it varied in a broader range than the previous study.

Total aerobic mesophilic bacteria loads of grape samples

TAMB loads of grape samples were given in Figure 2

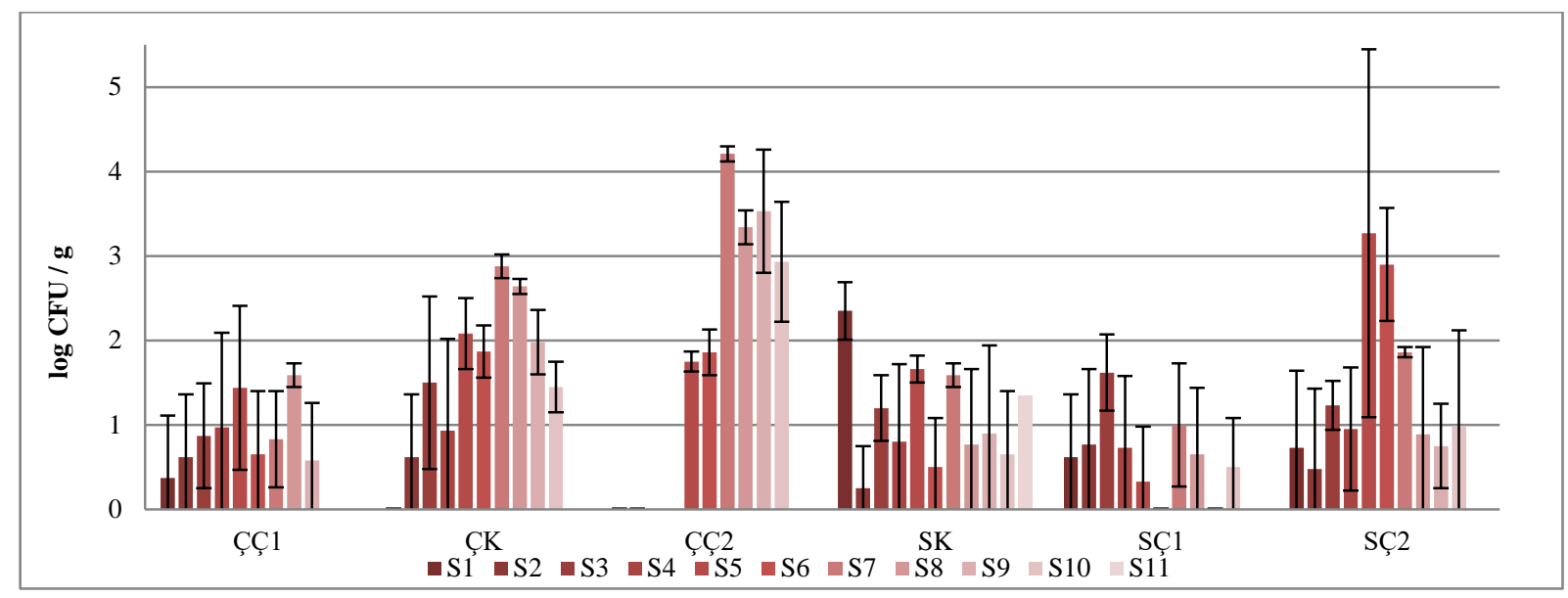

Figure 2. TAMB load of grape samples $(\log \mathrm{CFU} / \mathrm{g})(\mathrm{n}: 2)$ (Results are given as mean \pm standard deviation.)

-: No analysis was performed because grape samples were harvested.

In 2015, TAMB load of grape samples determined to range from $0.00 \pm 0.01$ to $1.50 \pm 1.02 \log \mathrm{CFU} / \mathrm{g}$ in Çayır district, while in Sulubahçe district they were ranged between $0.25 \pm 0.50$ and $2.35 \pm 0.34 \mathrm{log} \mathrm{CFU} / \mathrm{g}$. Also in 2016, TAMB loads were determined between $0.65 \pm 0.75$ and $4.21 \pm 0.09 \log \mathrm{CFU} / \mathrm{g}$ and $0.00 \pm 0.01$ and $3.27 \pm 2.18 \log$ CFU/g, respectively.

According to Kruskal Wallis statistical analysis; in 2015, the effect of only sampling days $(P=0.031)$ was significant on TAMB load, while the difference of the vineyard location $(P=0.083)$ and the effect of grape variety $(P=0.287)$ was found to be insignificant. In 2016, although the difference in vineyard location $(P=0.000)$ had a significant effect on TAMB load, the effect of sampling days $(P=0.158)$ and grape variety $(P=0.701)$ was not significant. When two years data were evaluated together, it was determined that the effect of the year $(P=0.000)$ vineyard location $(P=0.000)$ and sampling day $(P=0.000)$ has a significant effect on TAMB load and the effect of grape variety $(P=0.219)$ was insignificant.

In 2016, the TAMB load of Çavuş grapes in Çayır district was found to be approximately 4 times higher than in 2015, whereas, it is two times higher in Sulubahçe district. Moreover, TAMB loads of Çavuş grape in 2016 were higher than in both Cayır and Sulubahçe district in 2015. The $\mathrm{pH}$ value of Cavus grapes in 2015 was slightly higher than in 2016 . The titration acidity values were also close to each other in 2015 and 2016. Therefore, the reason for the high TAMB loads of Cavus grape in 2016 was not derived from $\mathrm{pH}$ and titration acidity. The reason for this may be the decrease in the mould and yeast loads, i.e. the low number of competitive microbiota. In the Karalahna grape, higher TAMB data were obtained in Cayır district in 2016, whereas in 2015 higher TAMB data was obtained in Sulubahçe district. In general, in 2016 higher TAMB loads were determined as years, whereas Sulubahçe district had higher TAMB load by area.
In general, the total count of aerobic bacteria in grapes is expected to be low. This is because the grapes have a low $\mathrm{pH}$ value and high sugar content. In addition, bacteria develop at neutral $\mathrm{pH}$ levels, and yeast and mould microorganisms, which are competitive flora in grapes, are the other factors that are limiting the bacterial growth (Renouf et al., 2005). In our study, the TAMB load could not be determined on some days in some vineyards, while on some days the TAMB load was found as over $4 \log \mathrm{CFU} / \mathrm{g}$ at some vineyards. When comparing the count of TAMB in grapes, various factors such as year of study, sampling time, type of grape taken, sampling method, the medium used should be taken into consideration. There may be differences due to these factors. Renouf et al. (2005) determined the count of anaerobic gram-positive bacteria in Merlot and Cabernet Sauvignon grapes from three different vineyards as $4.04 \mathrm{log}$ CFU/grapes. Martins et al. (2012) were determined that the total count of aerobic aerotolerant bacteria in organic grapes was range $<1$ to $1.71 \log \mathrm{CFU} / \mathrm{g}$, and $<1$ to $2.03 \log \mathrm{CFU} / \mathrm{g}$ in inorganic grapes. In our study, the total aerobic mesophilic bacteria count ranged between 0.00 and $4.21 \mathrm{log}$ CFU/g. In some of our samples, the TAMB load was below the detectable level like it was reported by Martins et al. (2012). Martins et al. (2013) reported the load of culturable aerobic and/or aerotolerant bacteria, as $4.52 \pm 0.04-4.65 \pm 0.09 \log \mathrm{CFU} / \mathrm{g}$ which is higher our results.

\section{Yeast loads of grape samples}

Two different media were used in determining the yeast load of grape samples. Yeast loads of grapes determined in DRBC medium were given in Figure 3a and in the DG18 medium were presented in Figure 3b.

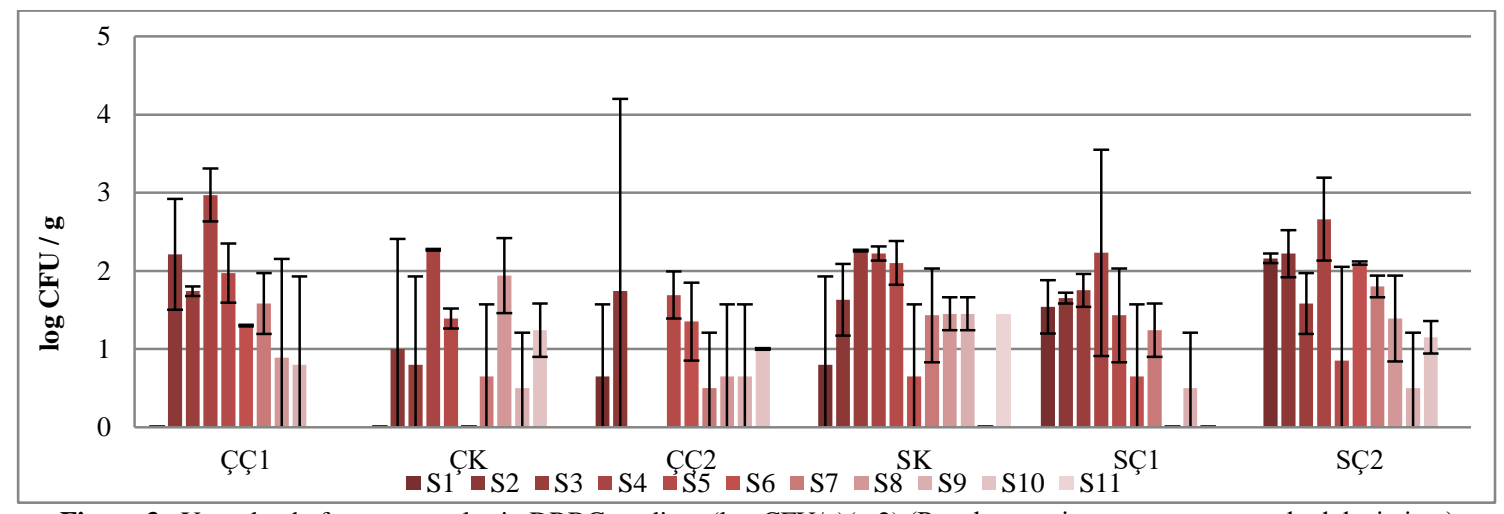

Figure 3a Yeast load of grape samples in DRBC medium $(\log \mathrm{CFU} / \mathrm{g})(\mathrm{n}: 2)$ (Results are given as mean \pm standard deviation.)

-: No analysis was performed because grape samples were harvested. 


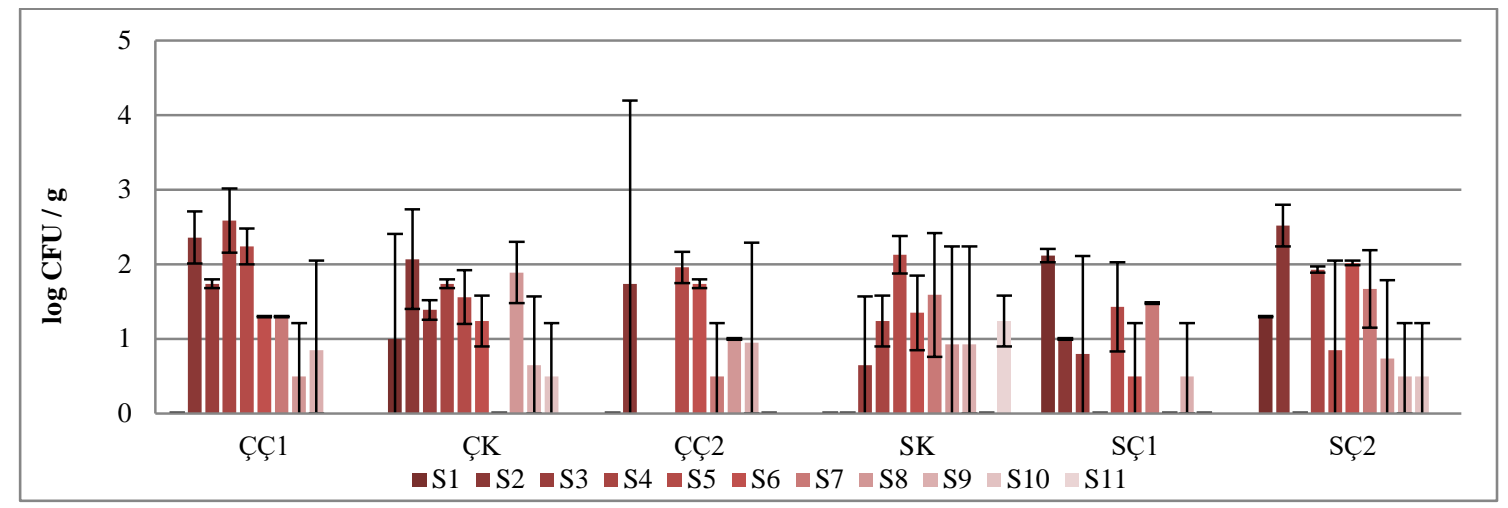

Figure 3b Yeast load of grape samples in DG18 medium $(\log C F U / g)(n: 2)$ (Results are given as mean \pm standard deviation.)

-: No analysis was performed because grape samples were harvested.

The yeast loads in DRBC medium ranged from $0.00 \pm 0.01$ to $2.97 \pm 0.34 \mathrm{log}$ CFU/g in 2015, whereas in 2016 ranged from $0.00 \pm 0.01$ to $2.10 \pm 0.02 \mathrm{log} \mathrm{CFU} / \mathrm{g}$ When the DG18 was used; it was found between $0.00 \pm 0.01$ and $2.52 \pm 0.28 \mathrm{log}$ CFU/g, in 2015 and between $0.00 \pm 0.01$ and $2.24 \pm 0.24 \mathrm{log}$ CFU/g in 2016. In both grape varieties, it was determined that the yeast load on DRBC medium was a bit higher than the DG18 medium. According to Kruskal Wallis statistical analysis, in 2 years of sampling, the effect of sampling year $(P=0.000)$, sampling day $(P=0.000)$ and vineyard location $(P=0.040)$ on the load of yeasts obtained from DRBC medium were statistically significant, whereas the effect of grape variety $(P=0.691)$ was not significant. In this respect, it can be said that DRBC yeast loads of grapes are affected by meteorological conditions. However, It was determined that only the sampling day $(P=0.002)$ had a significant effect on the yeast loads in DG18 medium, year $(P=0.450)$, grape variety $(P=0.830)$ and vineyard location $(P=0.228)$ was insignificant. When we compared the yeast loads obtained with DRBC medium and DG18 medium, it was determined that the difference between the media $(P=0.006)$ was significant.

As a result; yeast count was higher in DRBC medium than DG18 medium. Regardless of the medium, the effect of sampling day on the yeast load of grapes was found to be statistically significant. The fact that the sampling day is essential regarding the yeast load may indicate that the load is affected by meteorological conditions and the maturation of grapes. The change of air humidity and wind speed and direction can affect the microbiota on grapes. Also, change in $\mathrm{pH}$, WSDM and TA values depending on maturation may affect the group of microorganisms to be found on the grape surface. Particularly the competitive mould and bacteria groups in the microbiota were determined as other factors that may affect the yeast load.

Generally; in studies conducted on yeast loads of grapes, researchers reported different yeast loads. There are many different reasons for this. Among these reasons, grape varieties, sampling time, harvesting region, the physical condition of grapes, the maturity of grapes, analysis methods used in determining the yeast loads, viticulture methods, and methods used in pest control in vineyards can be listed. Therefore, researchers found different results in different studies. Renouf et al. (2005) also reported that the yeast load of grapes increased significantly during maturation. However, in our study, it was determined that the yeast load did not change due to maturation. Raspor et al. (2006) reported that the yeast load in different grape varieties was between 3.95 and $6.13 \log \mathrm{CFU} / \mathrm{mL}$. They determined that the yeast mycobiota at the surface of the grapes differ in regions. In our study, it was determined that yeast load vary according to sampling day and vineyard locations in both grape varieties. Even the highest yeast load in the samples of this study was found to be lower than the level determined by Raspor et al. (2006). Li et al. (2010) reported that yeast loads in different grape varieties ranged between 2.42-5.05 $\log \mathrm{CFU} / \mathrm{mL}$. In our study, it was determined that the yeast load was lower than the yeast loads obtained in previous studies and even in some samples the yeast load was below the detectable level. This situation depends on the grape variety and meteorological conditions as well as the analysis methods.

\section{Mould load of grape samples}

Two different media were used for mould counts for two reasons. The first reason was to determine how the microbial count result was affected by the medium. The second reason was to determine how the isolates of fungi to be imported were affected by the differentiation of the medium.

Two medium performances are also compared in the determination of mould loads as well as yeast loads. The mould loads of the grapes on the DRBC medium and the DG18 medium were given in Figure 4a and in Figure $4 \mathrm{~b}$ respectively.

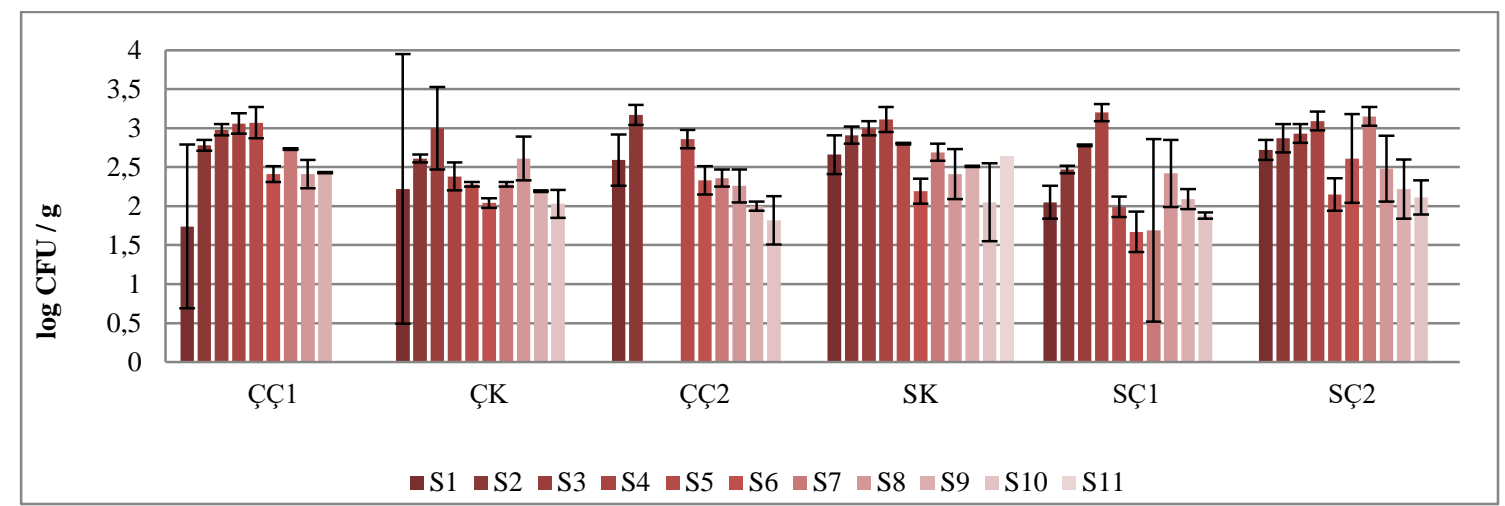

Figure 4a Mould load of grape samples in DRBC medium (log CFU/g)(n:2) (Results are given as mean \pm standard deviation.) -: No analysis was performed because grape samples were harvested. 


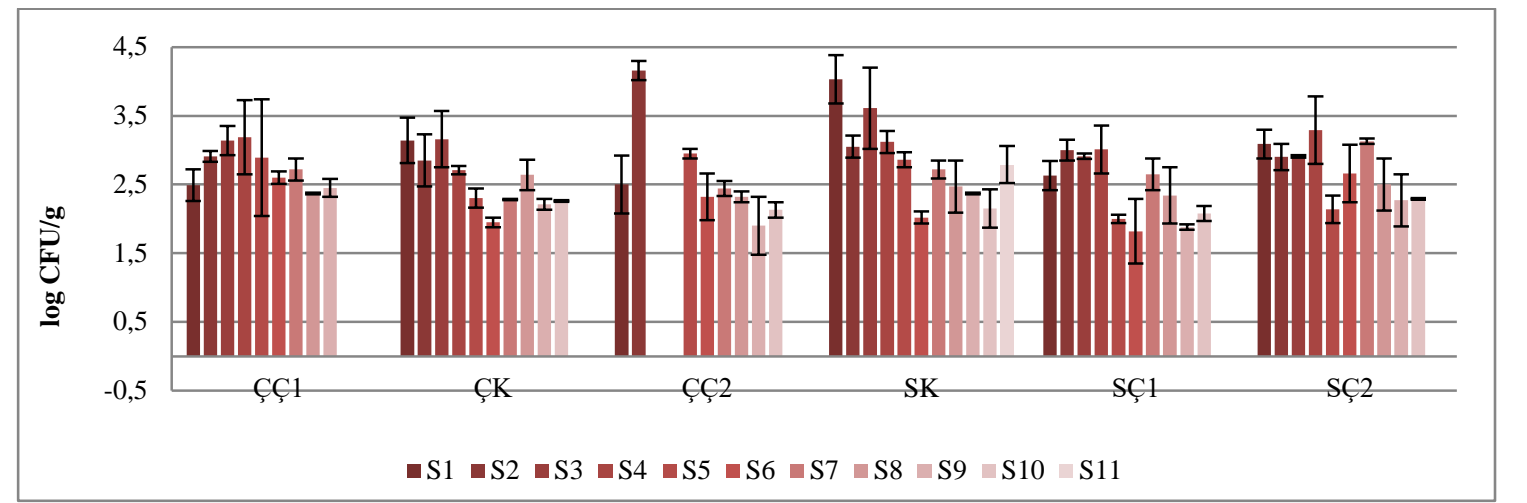

Figure 4b Mould load of grape samples in DG18 medium (log CFU/g)(n:2) (Results are given as mean \pm standard deviation.)

: No analysis was performed because grape samples were harvested

The mould load of grape samples on DRBC medium was between $1.74 \pm 1.05$ and $3.20 \pm 0.11 \log \mathrm{CFU} / \mathrm{g}$ in 2015; while in 2016, it was between $1.67 \pm 0.26$ and $3.15 \pm 0.12 \log \mathrm{CFU} / \mathrm{g}$ as shown in Figure 4a and 4b. It is observed that the mould load for both grapes is higher in the grapes found both in Sulubahçe in both years. In 2015, the mould load of grape samples with DG18 medium was between $2.49 \pm 0.23$ and $4.16 \pm 0.14 \log \mathrm{CFU} / \mathrm{g}$; in 2016 it was between $1.82 \pm 0.47$ and $2.95 \pm 0.07 \log \mathrm{CFU} / \mathrm{g}$. In 2015, more mould load was determined in the DG18 medium than in 2016 .

In general; the mould load in the DG18 medium is higher than or equal to the mould load determined on DRBC medium on most sampling days. When we consider the mould loads regarding grape varieties; it was determined that the mould load of Çavus grape was higher than Karalahna grapes in both locations and sampling years. This difference in mould load may have been due to the thinness of the skin of the Çavus grape and the protective effect of the high content of phenolic compounds in Karalahna grapes.

According to the non-parametric Kruskal Wallis statistical analysis, the effect of the year $(P=0.000)$, the vineyard location $(P=0.012)$ and the sampling day $(P=0.000)$ were a significant impact on the mould load determined on DRBC medium, while the grape variety $(P=0.814)$ was insignificant $(P<0.05)$. When we evaluate the DG18 data; it was determined that the effect of the year $(P=0.000)$ and sampling day $(P=0,000)$ was significant, while the effect of the vineyard $(P=0.090)$ and grape variety $(P=0.658)$ was insignificant. When we compared the DRBC medium with DG18 medium, it was determined that the difference between the mould loads $(P=0.010)$ was significant. Also, it was seen that the mould load is more in DG18, while more mould genus is determined in DRBC medium.

Taniwaki et al. (2001) evaluated the mould and yeast counts in DRBC and DG18 agar medium in various food products. They reported that in some food products, DRBC and DG18 counts were similar, whereas, in some food groups, DRBC counts were higher than DG18 counts. Similarly, in our study, some of the counts were at the same level in both media, however, in some samples, the counts on the DG18medium were higher than the DRBC medium.

There are many studies on the determination of the mould load of grapes. The researchers obtained different data about the microbiota of the grapes. These data were differed due to many other factors such as grape variety, grape maturity, physical damage in grapes, meteorological conditions, geographical location of the vineyard, time of grape sampling, sampling methods, cultivation practices applied in the vineyard, pest control method applied in the vineyard and plating techniques (Raspor et al., 2006; Serra et al., 2006). Therefore, it is difficult to compare our research with the literature. Nevertheless, despite all these factors, when the mould load of the grapes used in this study was compared with other researches it was found that similar mould loads were obtained with Medina $e$ al. (2005) and Sen et al. (2016). While Meyvaci et al. (2012) and Chunmei et al. (2013) have determined higher mould loads than our results. According to these data, it can be said that mould load was mainly affected by meteorological conditions and maturation of grapes. Meteorological conditions, especially humidity and wind speed affect the number of moulds and mould variety. Also, it can be seen that the maturation of grapes (nutritional change of the grape) may affect both the number of mould mycobiota and the mould diversity found on the grape surface.

\section{Distribution of mould species in grapes samples}

In 2015 and 2016, a total of 2264 isolates were collected. The most isolated species were Cladosporium spp. (29\%), Alternaria spp. (18\%) and Penicillium spp. (18\%). Aspergillus spp. isolates were found to be $14 \%$. The rate of unspecified sterile hyphae was $17 \%$, and Rhizopus spp. and other species were $2 \%$. The data on the distribution of these isolates were given in Figure 5.

In 2015, a total of 884 isolates was collected from DRBC. When we evaluate the isolates obtained at the genus level, Penicillium (40.38\%) was a most isolated genus in grape samples in 2015. The other genera found in the grapes were Aspergillus (21.38\%), Cladosporium (16.9\%) and Alternaria (15.72\%). The least found mould genera were Chaetomium (0.11\%), Epicoccum (0.11\%), Fusarium $(0.23 \%)$, Rhizopus $(0.68 \%)$, Trichoderma $(0.23 \%)$ and Ulocladium $(0.23 \%)$ However, 35 of the isolates $(3.96 \%)$ were identified as sterile hyphae. When we evaluate the isolates taken in 2015 by region, it was determined that Aspergillus and Penicillium species were found more in the vineyards of Cayır district. In the Sulubahçe district, it was determined that the most isolated genus varies according to the sampling day and grape variety

In 2016, 907 isolates were collected from DRBC medium. Cladosporium was the most isolated genus with a ratio of $34.40 \%$ in these isolates. In the mould microbiota of grapes, the second intense genus appears to be Alternaria. However, Aspergillus spp. and Penicillium spp. were found to be $9.92 \%$ and $3.75 \%$, respectively. Rhizopus spp. was found to be $5.07 \%$. Chaetomium spp. (0.11\%), Epicoccum spp. (1.55\%), Fusarium spp. (0.88\%), Trichoderma spp. $(0.55 \%)$ and Ulocladium spp. (0.66\%) were found to be less than $2 \%$. In addition, the number of sterile hyphae was determined to be $219(24.15 \%)$. When we examine the isolates of 2016 in terms of location; Alternaria and Cladosporium species were the most intense genera in both Çayır and Sulubahçe districts. The same situation was determined for Karalahna grape too. It was determined that the mould variety changed within two years,. It was thought that this was due to the meteorological conditions of 2016. It explained the increase in the proportion of moulds that were resistant to low water content because the year 2016 was defined as severely dry.

In 2016, the number of isolates from the DG18 medium was 473. In addition to the low number of isolates taken from the DG18 medium, it was determined that the diversity of moulds was also limited. In 2016, the most intense species was Cladosporium spp. (43.34\%) in both regions and grapes. Alternaria spp. $(18.60 \%)$ was the second one. The ratio of Aspergillus isolates was 6.98\%, and the ratio of Penicillium isolates was only $4.87 \%$.

In previous studies, the prevalence of mould variety found in grapes, dominant species and isolated genera are different in each study due to many factors such as grape varieties, the period and year of collection of grapes, the maturity degree of grape, the location of the vineyards, meteorological conditions. However, our results are in parallel with the studies in general (Sage et al., 2004; Garcia-Cela et al., 2015; Garmendia and Vero 2016; Oliveri et al., 2017; Lorenzini et al., 2018). In our study, Alternaria, Aspergillus, Cladosporium and Penicillium species were the most frequently isolated species like in many other studies. In addition, it was determined that the dominant mould type not change with the maturation of the grapes, whereas it could be changed according to the sampling year, vineyard location and grape variety. It was also determined that the species that were isolated less frequently showed variability in previous studies and in our study they were found to be Chaetomium spp., Epicoccum spp., Fusarium spp., Rhizopus spp., Trichoderma spp., and Ulocladium spp in this study. Whereas, Bell et al., (2006) reported Arthrinium, Botrytis, Dreschlera, Epicoccum, Fusarium, Humicola, Phoma and Staphylocotrichum spp as the less frequently isolated moulds.

\section{Aspergillus spp. isolates}

The number of Aspergillus isolates obtained from DRBC medium was different in 2015 and 2016; 189 isolates were taken in 2015, and only 90 isolates were taken in 2016. In DG18 medium, only 33 isolates were collected in 2016. In all isolates, It was determined that 281 Aspergillus isolates were found $(90.06 \%)$ as black Aspergillus and 31 isolates were found as the other Aspergillus species. The number of isolates taken in Çayır district was higher in both years. It can be said that Aspergillus contamination was higher in Çavus grapes than in Karalahna grapes. The Çavuş grapes of Çayır district seem to have the highest number of isolates in both sampling years.

Fifty four of the isolates were selected based on colony morphology and characteristics in Coconut Cream Agar (CCA), Aspergillus flavus/ parasiticus agar (AFPA), CYA, MEA, and CREA media (Dryer and McCammon, 1994 Samson et al., 2007; Samson et al., 2010; Samson et al., 2014). They were phenotypically identified at the species level. Out of 54 isolates, $85.19 \%$ were 
black Aspergillus, and $14.81 \%$ were other Aspergillus species. 39\% of 54 isolates were A. niger / A. acids (21), $44 \%$ of them were A. carbonarius (24), $5 \%$ of $A$. flavus (3) and $4 \%$ of A. candidus (2), $2 \%$ of A. terreus (1), $2 \%$ of A. calidoustus (1), $2 \%$ of A. sydowii (1) and $2 \%$ of A. ibericus (1).

Aspergillus genus was found in many grapes varieties. However, frequency and species diversity vary according to regions and grape varieties. In our study, especially black Aspergillus species were isolated from grapes. The other researchers also isolated A. carbonarius and A. niger species frequently as in our study (Battilani et al., 2006; Serra et al., 2006; Lasram et al., 2012; García Cela et al., 2015; Garmendia and Vero, 2016; Oliveri et al., 2017; Pantelides et al., 2017). One isolate was identified as A. ibericus which was also reported in Serra et al. (2006). Some researchers reported that they isolated uniseriate Aspergillus spp such as; A. parasiticus, A. tubingensis, A. welwitshiae, A. paradoxus, A. westerdijkiae, A. versicolor, A. niveus, A. wentii, A. aculeatus and A. japonicus. (Battilani et al., 2006; Serra et al., 2006; Lasram et al., 2012; García-Cela et al., 2015; Garmendia and Vero, 2016; Pantelides et al., 2017) Aspergillus species in grapes are not only important because of being an important part of mycobiota, but also because of mycotoxins they produce.

A

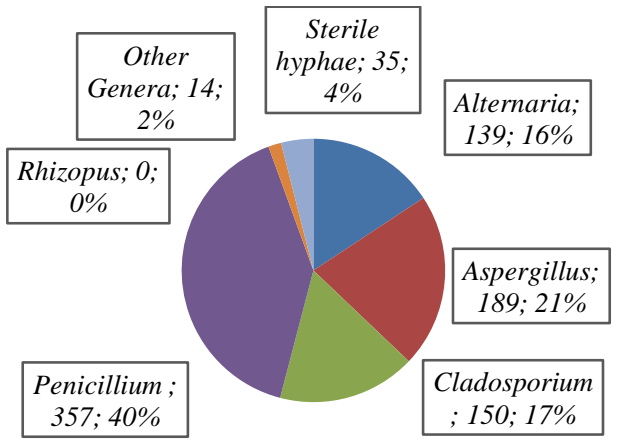

C

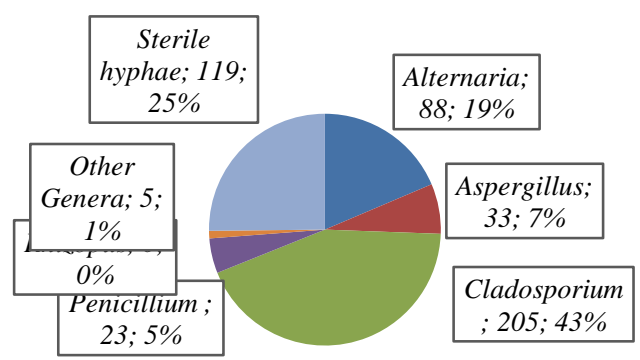

D

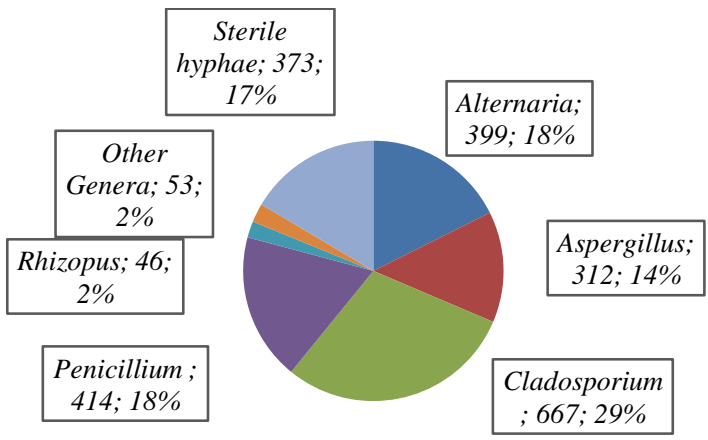

Figure 5 A) Distribution of DRBC isolates at the genus level in 2015. B) Distribution of DRBC isolates at genus level in 2016. C) Distribution of DG18 isolates at the genus level in 2016. D) Distribution of mould isolates obtained in 2015 and 2016

\section{OTA production}

54 isolates were evaluated by TLC (Özcan, 2017) and 6 isolates were selected from the possible OTA producer. OTA production of 6 isolates was determined by HPLC-FLD. One A. calidoustus isolate produced $0.80 \mathrm{ng} / \mathrm{g}$ and one $A$. sydowii isolate produced $0.89 \mathrm{ng} / \mathrm{g}$ of ochratoxin A. The selected four A. niger / acidus (K1657, K1641, K1658, and $\mathrm{K} 284$ ) isolates were determined to produce 1.28 $\mathrm{ng} / \mathrm{g}, 1.32 \mathrm{ng} / \mathrm{g}, 2.30 \mathrm{ng} / \mathrm{g}$ and $74.01 \mathrm{ng} / \mathrm{g}$ ochratoxin A respectively.

Pantelides et al. (2017) reported 3 of A. niger isolates, and one of A. welwitschia isolate produced an average of 9.1 to $23.9 \mathrm{ng} / \mathrm{g}$ OTA. In our study, it was determined that $A$.niger isolates produced OTA in amounts ranging from 1.28 to $74.01 \mathrm{ng} / \mathrm{g}$, and an A.niger isolate produced a very high amount of OTA compared to the other study. Sen et al. (2016) determined that $59.4 \%$ of the $A$. niger isolates produced OTA between 0.5 and $809.70 \mathrm{ng} / \mathrm{g}$. They found that three $(4.34 \%)$ A. niger isolates had the highest OTA production capacity and produced OTAs of $809.70 \pm 9.09,87.58 \pm 16.89$ and $45.44 \pm 18.78 \mathrm{ng} / \mathrm{g}$. In our study, the highest OTA production was determined to be in one A. niger isolate as 74.01 $\mathrm{ng} / \mathrm{g}$

A. niger, A. carbonarious, A. tubingensis and A. ochraceus isolates obtained from grapes were determined as main ochratoxin A producing strains. However, we could not perform ochratoxin analysis for A. carbonarious isolates by HPLC but we can only evaluate them as a probable producer in TLC (Özcan, 2017) However, unlike the previous studies, isolates that identified as A. sydowii and $A$. calidoustus were also determined ochratoxin A producers by using HPLC. There is no report about the ochratoxin production of these species. Varga et al. (2015) reported that Aspergillus sydowii produces griseofulvin and A.calidoustus produced ophiobolin. The researchers also stated that griseofulvin is a chlorinecontaining pentaketide and ochratoxin is a cyclic pentaketide (Varga et al., 2015; Wang et al., 2016) More studies on metabolite production of these species should be done because they were produced in a similar metabolic pathway (Zhang et al., 2008). So it was concluded that A. sydowii had the possibility of producing ochratoxin. However, since molecular identification cannot be performed, type verification did not complete. With the identification of this species on the basis of molecular methods, perhaps A. sydowii will be reported as ochratoxin producers. In addition, no information was found in the literature regarding the production of ochratoxin A of the A. calidoustus. If the identification of this isolate is confirmed by molecular techniques, it will be introduced to the literature the first time that $A$. calidoustus produced OTA.

\section{CONCLUSION}

Microbial loads of Bozcaada Çavuş and Karalahna grapes were determined for the first time. It was determined that the mould loads of Bozcaada Çavuş and Karalahna grapes were affected by meteorological conditions. Microbial loads of grapes were determined to be affected from sampling year, vineyard location and sampling days. $(P<0.05)$. It was determined that higher mould counts and higher mould species diversity were obtained in DRBC medium. A total of 2264 isolates belonging to 10 genera and sterile mycelia were obtained from mycobiota in 2015 and 2016. The most common genera were found to be Alternaria, Aspergillus, Cladosporium and Penicillium. It had been determined that the rates of these species vary by year and sampling day. Three hundred twelve Aspergillus isolates were taken from grapes. Black Aspergillus species were dominant in Aspergillus species isolated. Among the selected isolates, the ochratoxigenic species such as A. niger, and A. carbonarius were also isolated. In addition, the OTA production in 4 black Aspergillus and 2 green Aspergillus isolates were determined by HPLC. These results show that there may be a risk of human exposure to mycotoxins through the consumption of grape and grape products. A future analysis of the three leading compounds among Aspergillus toxins (Ochratoxin, Aflatoxin, and Fumonisin) in grapes as well as during the 
different process (raisin, grape juice, wine and molasses) will contribute understanding the real exposure of consumers to Aspergillus mycotoxins.

Acknowledgement:This study was supported by Scientific Research Fund of Canakkale Onsekiz Mart University as a part of the doctoral thesis (project no FDK-2017-1191), and Gülçin ÖZCAN (ATEŞ) received a scholarship during doctoral education by TÜBİTAK 2211-A General National PhD Scholarship Program.

\section{REFERENCES}

ANONYMOUS, 2015. http://bozcaada.bel.tr/bozcaada/bozcaada-hakkinda/date of access: 10.06.2015.

AOAC, 2002. Ochratoxin a in Barley. AOAC Official Method 2000.03.

BARATA, A., MALFEITO-FERREIRA, M., LOUREIRO, V., 2012. The Microbial Ecology of Wine Grape Berries. International Journal of Food Microbiology, 153, 243-259. http://dx.doi.org/10.1016/j.ijfoodmicro.2011.11.025 BATTILANI, P., GIORNI, P., BERTUZZI, T., FORMENTI, S., PIETRI, A., 2006. Black Aspergilli and Ochratoxin A in Grapes in Italy. Internationa Journal of Food Microbiology, 111, 53-60. http://dx.doi.org/10.1016/j.ijfoodmicro.2006.03.006

BEJAOUI, H., MATHIEU, F., TAILLANDIER, P., LEBRIHI, A., 2006. Black Aspergilli and Ochratoxin A Production in French Vineyards. International Journal of Food Microbiology, 111, 46-52. http://dx.doi.org /10.1016/j.ijfoodmicro.2006.03.004

BEUCHAT, L.R., 1987. Food and Beverage Mycology. 2nd edition, Springer US, New York, USA.

CHUNMEI, J., JUNLING, S., QI'AN, H., YANLIN, L., 2013. Occurrence of Toxin Production Fungi in Intact and Rotten Table and Wine Grapes and Related Influencing Factors. Food Control, 31, 5-13. http://dx.doi.org/10.1016/j.foodcont.2012.09.015

DARDENiZ, A., BAHAR, E., SiMSSEK, L., 2007. Bozcaada Bağcılığındaki Gelişmeler, Sorunlar ve Öneriler. Çanakkale Araştırmaları Türk Yıllı̆̆ı, Bahar, 147-161.

DRYER,S.K.,MCCAMMON,S.,1994. Detection of Toxigenic isolates of Aspergillus flavus and related species on Coconut Cream agar. Journal of Applied Bacteriology,76,75-78. http://dx.doi.org/10.1111/j.1365-2672.1994.tb04418.x

FLEET, G.H., 1999. Microorganisms in Food Ecosystems. International Journal of Food Microbiology, 50, 101-117. https://dx.doi.org/10.1016/S0168 1605(99)00080-X

GARCÍA-CELA, E., CRESPO-SEMPERE, A., GIL-SERNA, J., PORQUERES A., MARIN, S., 2015. Fungal Diversity, Incidence and Mycotoxin Contamination in Grapes from Two AgroClimatic Spanish Regions with Emphasis on Aspergillus species. J Sci Food Agric, 95, 1716-1729. http://dx.doi.org /10.1002/jsfa.6876

GARMENDIA, G., VERO, S., 2016. Occurrence and Biodiversity of Aspergillus Section Nigri on 'Tannat' Grapes in Uruguay. International Journal of Food Microbiology, 216, 31-39. http://dx.doi.org /10.1016/j.ijfoodmicro.2015.08.020 GÜVEN, S., 2008. Șarap Üretimi ve Kalite Kontrol. Çanakkale Onsekiz Mar Üniversitesi Yayınları, 316, Canakkale.

LASRAM, S., OUESLATI, S., MLIKI, A., GHORBEL, A., SILAR, P., CHEBIL S., 2012. Ochratoxin A and Ochratoxigenic Black Aspergillus Species in Tunisian Grapes Cultivated in Different Geographic Areas. Food Control, 25 75-80. https://dx.doi.org/10.1016/j.foodcont.2011.10.006

LI, S.-S., CHENG, C., LI, Z., CHEN, J.-Y., YAN, B., HAN, B.-Z., REEVES, M. 2010. Yeast Species Associated with Wine Grapes in China. International Journal of Food Microbiology, 138, 85-90. http://dx.doi.org/10.1016/j.ijfoodmicro.2010.01.009

LORENZINI, M., SIMONATO, B., FAVATI, F., BERNARDI, P., SBARBATI A., ZAPPAROLI, G., 2018. Filamentous fungi associated with natural infection of noble rot on withered grapes. International Journal of Food Microbiology, 272, 83-86. http://dx.doi.org/10.1016/i.ijfoodmicro.2018.03.004

MARTINS, G., LAUGA, B., MIOT-SERTIER, C., MERCIER, A., LONVAUD, A., SOULAS, M.-L., SOULAS, G., MASNEUF-POMARÉDE, I., 2013. Characterization of Epiphytic Bacterial Communities from Grapes, Leaves, Bark and Soil of Grapevine Plants Grown, and Their Relations. PLoS ONE, 8(8), e73013. http://dx.doi.org /10.1371/journal.pone.0073013

MARTINS, G., MIOT-SERTIER, C., LAUGA, B., CLAISSE, O., LONVAUDFUNEL, A., SOULAS, G., MASNEUFPOMARÈDE, I., 2012. Grape Berry Bacterial Microbiota: Impact of the Ripening Process and The Farming System International Journal of Food Microbiology, 158, 93-100. http://dx.doi.org /10.1016/j.ijfoodmicro.2012.06.013

MEDINA, A., MATEO, R., LÓPEZ-OCAÑA, L., VALLE-ALGARRA, F.M., JIMÉNEZ, M., 2005. Study of Spanish Grape Mycobiota and OchratoxinA Production by Isolates of Aspergillus tubingensis and Other Members of Aspergillus Section Nigri. Applied and Environmental Microbiology, Aug, 46964702. http://dx.doi.org/10.1128/AEM.71.8.4696-4702.2005

MELKI BEN FREDJ, S., CHEBIL, S., LEBRIHI, A., LASRAM, S., GHORBEL, A., MLIKI, A., 2007. The occurrence of Pathogenic Fungal Species in Tunisian Vineyards. International Journal of Food Microbiology, 113, 245-250. http://dx.doi.org/10.1016/j.ijfoodmicro.2006.07.022

MEYVACI, K.B., AKSOY, U., ELTEM, R., ALTINDIŞLI, A., TASSIN, E. 2012. Effect of Yearly Conditions and Management Practices on Ochratoxin A Production in Sultana Seedless Vineyards. Food Additives and Contaminants Part A, 29(7), 1157-1167. http://dx.doi.org/10.1080/19440049.2012.681399 OLIVERI, C., BELlA, P., TESSTOR, M., CATARA, V., ROSA, L.R., 2017 Grape and Environmental Mycoflora Monitoring in Old, Traditionally Cultivated Vineyards on Mount Etna Southern Italy. J Sci Food Agric, 97, 65-73. http://dx.doi.org/10.1002/jsfa.7683

ÖZCAN, G., 2017. Bozcaada Karalahna ve Çavuș Üzümlerinin Olgunlașma Sürecinde Mikrobiyal Yükünün, Küf Türlerinin ve Mikotoksin Profillerinin Belirlenmesi. Çanakkale Onsekiz Mart University, PhD thesis, Çanakkale, Turkey.

PANTELIDES, I.S., ARISTEIDOU, E., LAZARI, M., TSOLAKIDOU, M.-D., TSALTAS, D., CHRISTOFIDOU, M., KAFOURIS, D., CHRISTOU, E., IOANNOU, N., 2017. Biodiversity and Ochratoxin A Profile of Aspergillus Section Nigri Populations Isolated From Wine Grapes in Cyprus Vineyards. Food Microbiology, 67,106-115. http://dx.doi.org /10.1016/j.fm.2017.06.010

PITT, J.I., HOCKING, A.D., 2009. Fungi and Food Spoilage. Springer. http://dx.doi.org/10.1007/978-0-37892207-2

RASPOR, P., MILEK, D.M., POLANC, J., MOŽINA, S.S., ČADEŽ, N., 2006 Yeast Isolated from Three Varieties of Grapes Cultivated in Different Locations of The Dolenjska Vine-Growing Region, Slovenia. International Journal of Food Microbiology, 109, 97-102. http://dx.doi.org/10.1016/j.ijfoodmicro.2006.01.017 R-BIOPHARM 2003. Immunoaffinity column for sample cleans up prior to analysis of Ochratoxin A, Art. No. R1303, R-Biopharm GmbH, Darmstadt Germany.

RENOUF, V., CLAISSE, O., LONVAUD-FUNEL, A., 2005. Understanding The Microbial Ecosystem on the Grape Berry Surface through Numeration and Identification of Yeast and Bacteria. Australian Journal of Grape and Wine Research, 11, 316-327. https://dx.doi.org/10.1111/j.1755-0238.2005.tb00031.x

SAGE, L., GARON, D., SEIGLE-MURANDI, F., 2004. Fungal Microflora and OchratoxinA Risk in French Vineyards. J. Agric. Food Chem., 52, 5764-5768. http://dx.doi.org/10.1021/jf049497c

SAMSON, R.A., HOUBRAKEN, J., THRANE, U., FRISHAD, J.C. ANDERSEN, B., 2010. Food and Indoor Fungi. CBS-KNAW Fungal Biodiversity Centre, P.O. Box85167, 3508 AD Utrecht, The Netherlands

SAMSON, R.A., NOOMIN, P., MEIJER, M., HOUBRAKEN, J., FRISVAD, J.C., VARGA, J., 2007. Diagnostic Tools to Identify Black Aspergilli. Studies In Mycology, 59, 129-145. http://dx.doi.org/10.3114/sim.2007.59.13]

SAMSON, R.A., VISAGIE, C.M., HOUBRAKEN, J., HONG, S.-B., HUBKA V., KLASSEN, C.H.W., PERRONE, G., SEIFERT, K.A., SUSCA, A., TANNEY, J.B., VARGA, J., KOCSUBÉ, S., SZIGETI, G., YAGUCHI, T. FRISVAD, J.C., 2014. Phylogeny, Identification and Nomenclature of The Genus Aspergillus. Studies In Mycology, 78, 141-173. http://dx.doi.org/10.1016/j.simyco.2014.07.004

SERRA, R., LOURENCO, A., ALIPIO, P., VENÂNCIO, A., 2006. Influence of The Region of Origin on The Mycobiota of Grapes with Emphasis on Aspergillus and Penicillium Species. Mycological Research, 110, 971-978. http://dx.doi.org /10.1016/j.mycres.2006.05.010

ȘEN, L., OCAK, İ., NAS, S., ŞEVIK, R., 2016. Effects of Different Drying Treatments on Fungal Population and Ochratoxin A Occurrence in Sultana Type Grapes. Food Additives \& Contaminants, 33(9), 1444-1455. http://dx.doi.org/10.1080/19440049.2016.1217066

TANIWAKI, M.H., SILVA, N.D., BANHE, A.A., IAMANAKA, B.T., 2001 International Association for Food Protection Comparison of Culture Media, Simplate, and Petrifilm for Enumeration of Yeasts and Molds in Food. Journal of Food Protection, 64(10), 1592- 1596. https://dx.doi.org/10.4315/0362-028X64.10.1592

TIAN, J., WANG, Y., ZENG, H., LI, Z, ZHANG, P., TESSEMA, A., PENG, X. 2015. Efficacy and Possible Mechanisms of Perillaldehyde in Control of Aspergillus niger Causing Grape Decay. International Journal of Food Microbiology, 202, 27-34. http://dx.doi.org/10.1016/j.ijfoodmicro.2015.02.022 TOURNAS, V.H., KATSOUDAS, E., 2005. Mould and Yeast Flora in Fresh Berries, Grapes and Citrus Fruits. International Journal of Food Microbiology, 105, 11-17. http://dx.doi.org/10.1016/j.ijfoodmicro.2005.05.002

VARGA, J., BARANYI, N., CHANDRASEKARAN, M., VÁGVÖLGYI, C., KOCSUBÉ, S., 2015. Mycotoxin Producers in the Aspergillus Genus: An Update. Acta Biologica Szegediensis, 59(2), 151-167.

WANG, Y., ZENG, X., ZHOU, Z., XING, K., TESSEMA, A., ZENG, H., TIAN, J., 2015. Inhibitory Effect of Nerol against Aspergillus niger on Grapes through a Membrane Lesion Mechanism. Food Control, 55, 54-61. https://dx.doi.org/10.1016/j.foodcont.2015.02.029

WANG, Y., WANG, L., LIU, F., WANG, Q., SELVARAJ, J.N., XING, F., LIU, Y., 2016. Ochratoxin A producing fungi, biosynthetic pathway and regulatory mechanisms. Toxins, 8(3), 83-97. http://dx.doi.org/10.3390/toxins8030083 ZHANG, M., WANG, W.L., FANG, Y.C., ZHU, T.J., GU, Q.Q., ZHU, W.M. 2008. Cytotoxic alkaloids and antibiotic nordammarane triterpenoids from the marine-derived fungus Aspergillus sydowi. Journal of Natural Products,71(6) 985-989. http://dx.doi.org/ 10.1021/np700737g 